\title{
AN EVALUATION OF SULPHUR FOR BROWN ROT CONTROL IN CENTRAL OTAGO STONEFRUIT
}

\author{
G.F. McLAREN, J.A. FRASER and D.G. LYNCH ${ }^{1}$ \\ HortResearch, Clyde Research Centre, Alexandra, R. D. 1, Central Otago \\ ${ }^{1}$ HortResearch, Hawke's Bay Research Centre, Havelock North, Hawke's Bay
}

\begin{abstract}
Monilinia fructicola (Wint.) Honey was controlled in the blossom blight and fruit brown rot stages in season-long programmes on nectarines, peaches and apricots using sulphur. The efficacy of three rates of sulphur $(80,120$ and $160 \mathrm{~g}$ ai/100 litres) was tested on two apricot cultivars, 'Sundrop' and 'CluthaGold'. Sulphur, applied from flowering to harvest, delayed ripening in apricots but caused no apparent damage to the leaves or fruit. Sulphur was also effective in trials to compare the timing of applications in relation to infection periods. Preinfection, postinfection and standard programmes were all effective, but a wet season complicated interpretation of infection period timing.
\end{abstract}

Keywords: brown rot, Monilinia fructicola, sulphur, apricots, nectarines, peaches

\section{INTRODUCTION}

Brown rot, caused by Monilinia fructicola (Wint.) Honey can be a major cause of crop loss in stonefruit (summerfruit). The fungicide programme for its control in commercial orchards is the single largest component of the current export spray programme, with up to 12 applications per season in Central Otago. While a range of fungicides is currently available for use over the flowering period, the choice is much reduced close to harvest, especially for some export markets. Available fungicides are likely to diminish further as sensitivity to the DMIs and dicarboximides declines (Elmer and Gaunt 1994; Braithwaiteet al. 1995) and international residue requirements become more restrictive (Cross et al. 1996). Growers of organic produce face an even more limited choice with sulphur and copper being their main options. Sulphur was used previously for brown rot control but was superseded by newer fungicides (Byrde and Willetts 1977). Recent trials in New Zealand have shown that sulphur/copper blends (McLaren and Fraser 1993; P. Elmer pers. comm.) and sulphur alone (McLaren and Fraser 1993,1994) reduced blossom blight and brown rot. Growers of export and local market fruit would benefit if sulphur were shown to be effective and safe to use on stonefruit. However, sulphur has a reputation for damaging some crops and the current registration label for sulphur carries a warning 'Do not use on apricots'. This paper describes experiments that investigate the effects of sulphur applications on brown rot incidence and fruit quality of apricots, as well as spray timing in relation to infection periods.

\section{METHODS}

Two experiments were conducted at Clyde Research Centre in 1995/96 on three year old nectarines and apricots. None of the trees had been treated previously with fungicides.

\section{Sulphur efficacy}

Four treatments were replicated three times on apricot cv. 'Sundrop' and 'CluthaGold' in a randomised block design, using three-tree plots, with one untreated tree between each plot and an untreated row between each treated row. The trees were 
at $4.5 \times 2 \mathrm{~m}$ spacings. Three rates of sulphur (Kumulus DF $800 \mathrm{gm} / \mathrm{kg}$ ) 80, 120 and 160 g ai were compared with an untreated control. The trees were sprayed to runoff with an experimental sprayer and handgun, applying approximately 5 litres per tree over flowering (11, 18 and 25 September 1995), during the growing season (13 October, 15 November, 15 December 1995) and prior to harvest (8 January 1996). No other fungicides or insecticides were applied. The block was irrigated and frost-protected by overhead sprinklers, with the exception of the morning of 20 November when a late frost thinned the crop again (hand thinned on 6 November). The number of blighted flowers and collapsed tips ('twig blight') present on each trial tree was recorded on 19 October 1995. At harvest, all the fruit were picked on 25 January ('Sundrop'), and 12 February 1996 ('CluthaGold'). The sample size per treatment ranged from 57-157 fruits for 'Sundrop' and 40 - 312 fruits for 'CluthaGold'. The fruit were packed in count-36 plastic liners in single layer cardboard trays, enclosed in plastic bags and held in the laboratory at $20^{\circ} \mathrm{C}$. Every second day, fruit with brown rot symptoms were identified, recorded and removed. On the day of harvest, the quality of 10 fresh fruit per replicate ( 30 per treatment) of both cultivars was evaluated by recording soluble solids content with an Atago digital refractometer, weight, firmness (kg force measured with an Effegi penetrometer and $8 \mathrm{~mm}$ tip) and skin colour on the blush and non-blush sides with a Minolta Chroma Meter II (D65 light source).

\section{Timing of sulphur applications in relation to the weather}

In the second trial, 0.2 ha blocks of three year old apricot cv. 'San Castrese', peach cv. 'Flamecrest', and nectarine cv. 'Fantasia' and 'Red Diamond', were divided into quarters containing 25 trees. Sulphur was applied to one of each of the quarters at 150 $\mathrm{g}$ ai/100 litres (Kumulus DF $187.5 \mathrm{~g} / 100$ litres) with an airblast sprayer calibrated to deliver 2000 litres per ha. according to whether 1) rain was predicted, 2) an infection period had occurred, or 3) the standard fungicide programme was due. One quarter remained untreated in each block. Preinfection and postinfection applications were made within 48 hours of an infection period whenever possible. Infection periods were determined using guidelines developed by Tate et al. (1995). Applications were carried out over the period from bloom to January. Preinfection applications were made on 21.9.95, 25.9.95 and 5.10.95. Two additional sulphur applications were made to all three fungicide-treated blocks on 23.11.95 and 19.1.96. Postinfection spray applications were made on 16.9.95, 25.9.95, 5.10.95 and 10.10.95. Four infection periods occurred over flowering with one on 15 September (full bloom of apricots, pink of nectarines), 24-27 September (petal fall of apricots, full bloom of nectarines) and on 3,4 and 8 October (petal fall of nectarines). The standard programme was applied on 14.9.95 (to 'San Castrese' and 'Flamecrest' only), 18.9.95, 2.10.95 and 10.10.95. The number of blighted flowers or collapsed tips per tree was recorded on the central nine trees in each quarter on 26 October 1995. On the day of harvest, the total number of fruit per tree and proportion with rots was recorded on the 25 trees in each quarter. A sample of 180 fruit (36 per row) was picked at random from each treatment, packed, stored and assessed as described above.

Data were analysed by analysis of variance, with arcsine transformation of percentages. Means were separated by Newman-Keuls test (Hintze 1989). Chroma meter readings were analysed for $\mathrm{L}^{*}$ (CIELAB lightness coefficient), hue and chroma (McGuire 1992).

\section{Sulphur efficacy}

\section{RESULTS}

The untreated trees of 'Sundrop' and 'CluthaGold' had more blighted flowers and tips than the treated trees. All three rates of sulphur reduced the level of infection on the flowers of 'Sundrop', but only the highest rate was better than the control on 'CluthaGold' ( $\mathrm{P}<0.05$, Table 1).

During storage, sulphur-treated 'Sundrop' fruit developed brown rot more slowly than the untreated sample. All three rates of sulphur produced similar levels of brown rot over the first eight days, but as the storage time extended to days 14 and 16, the 
middle rate $(120 \mathrm{~g})$ was the only one which continued to provide better control than the untreated $(\mathrm{P}<0.05)$. Cumulative losses due to brown rot reached $50 \%$ on day 8 in the untreated, and on day 13 in the sulphur $120 \mathrm{~g}$ treatment. Cumulative losses due to brown rot in storage were not reduced by the sulphur treatments compared with the control in 'CluthaGold' $(\mathrm{P}>0.05)$.

TABLE 1: Mean number of blighted flowers or collapsed tips per tree on two apricot cultivars at Clyde Research Centre on 19 October 1995. [Numbers within a column followed by the same letter were not significantly different by Newman-Keuls test $(P<0.05)]$.

\begin{tabular}{lcc}
\hline Rate/100 litres & Sundrop & CluthaGold \\
\hline sulphur 80g & $1.75 \mathrm{a}$ & $3.75 \mathrm{ab}$ \\
sulphur 120g & $4.89 \mathrm{a}$ & $3.33 \mathrm{ab}$ \\
sulphur 160g & $2.33 \mathrm{a}$ & $1.14 \mathrm{a}$ \\
untreated & $16.78 \mathrm{~b}$ & $6.67 \mathrm{~b}$ \\
$\mathrm{P}$ & $<0.001$ & 0.042 \\
\hline
\end{tabular}

Sulphur delayed ripening in both cultivars, particularly in 'Sundrop', where treated fruit had lower chroma readings $(\mathrm{P}<0.05)$ (but showed no difference in the hue or $\mathrm{L}^{*}$ readings), had lower soluble solids content (less sweet) and higher fruit firmness (kg force) compared with the untreated $(\mathrm{P}<0.05)$. The highest rate of sulphur also caused a reduction in fruit weight $(\mathrm{P}<0.05)$. Although the colour of 'CluthaGold' was not affected by the sulphur treatments, its average weight was reduced and firmness increased, especially at the highest rate $(\mathrm{P}<0.05)$ (data not presented).

Timing of sulphur applications

All the sulphur programmes reduced blossom blight incidence in 'Red Diamond' nectarine $(\mathrm{P}<0.05)$, but in 'Fantasia', only the preinfection programme was effective. None of the sulphur treatments were effective on 'San Castrese' apricot or 'Flamecrest' peach (Table 2).

TABLE 2: Mean number of blighted flowers or collapsed tips per tree at Clyde Research Centre on 26 October 1995. [Numbers within a column followed by the same letter were not significantly different by Newman-Keuls test $(\mathbf{P}<0.05)]$.

\begin{tabular}{lcccc}
\hline Treatment & San Castrese & Red Diamond & Fantasia & Flamecrest \\
\hline standard & 1.11 & $2.33 \mathrm{a}$ & $2.67 \mathrm{~b}$ & 1.75 \\
preinfection & 1.00 & $2.89 \mathrm{a}$ & $0.44 \mathrm{a}$ & 2.00 \\
postinfection & 0.56 & $1.22 \mathrm{a}$ & $2.89 \mathrm{~b}$ & 1.22 \\
untreated & 1.44 & $5.83 \mathrm{~b}$ & $3.44 \mathrm{~b}$ & 1.22 \\
$\mathrm{P}$ & $>0.05$ & 0.017 & 0.028 & $>0.05$ \\
\hline
\end{tabular}

At harvest, the level of brown rot in the fruit on untreated trees of 'Red Diamond' $(17 \%)$ and 'Flamecrest' (25\%) was very high. There were significant differences between the four treatments in all trial blocks with a consistently lower incidence of brown rot in the preinfection treatment than the control (Table 3). The effect of the other two sulphur programmes varied with cultivar.

'Fantasia' and 'Flamecrest' were both susceptible to rots in storage, irrespective of the field programme $(\mathrm{P}>0.05)$. Brown rot developed more slowly on the other two cultivars if they had been treated with sulphur, either just before or just after an infection period ('San Castrese') or just after an infection period ('Red Diamond') (Table 4). 
TABLE 3: The effect of timing sulphur applications on percentage ${ }^{1}$ of fruit infected on the tree at harvest at Clyde Research Centre.

\begin{tabular}{lccc}
\hline Treatment & Red Diamond & Fantasia & Flamecrest \\
\hline standard & $2.90 \mathrm{a}$ & $2.97 \mathrm{ab}$ & $13.3 \mathrm{a}$ \\
preinfection & $0.71 \mathrm{a}$ & $0.88 \mathrm{a}$ & $12.7 \mathrm{a}$ \\
postinfection & $0.52 \mathrm{a}$ & $4.79 \mathrm{~b}$ & $16.5 \mathrm{ab}$ \\
untreated & $16.92 \mathrm{~b}$ & $4.21 \mathrm{~b}$ & $25.2 \mathrm{~b}$ \\
$\mathrm{P}$ & $<0.001$ & 0.016 & 0.030 \\
\hline
\end{tabular}

${ }^{1}$ Means were arcsine transformed for ANOVA and back transformed for presentation. [Numbers in a column followed by the same letter were not significantly different by Newman-Keuls test $(\mathrm{P}<0.05)]$.

TABLE 4: The effect of timing sulphur applications on percentage ${ }^{1}$ fruit with brown rot after storage at $2^{\circ} \mathrm{C}$ on 'San Castrese' and 'Red Diamond' at Clyde Research Centre.

\begin{tabular}{lclc}
\hline & San Castrese & \multicolumn{2}{c}{ Red Diamond } \\
Treatment & Day 8 & Day 5 & 7 \\
\hline standard & $74.4 \mathrm{~b}$ & $34.4 \mathrm{a}$ & $98.9 \mathrm{~b}$ \\
preinfection & $43.9 \mathrm{a}$ & $61.1 \mathrm{ab}$ & $98.9 \mathrm{~b}$ \\
postinfection & $54.4 \mathrm{a}$ & $16.1 \mathrm{a}$ & $86.1 \mathrm{a}$ \\
untreated & $82.2 \mathrm{~b}$ & $86.1 \mathrm{~b}$ & $100 \mathrm{~b}$ \\
$\mathrm{P}$ & 0.016 & $<0.001$ & 0.013 \\
\hline
\end{tabular}

${ }^{1}$ Means were arcsine transformed for ANOVA and back transformed for presentation. [Numbers in a column followed by the same letter were not significantly different by Newman-Keuls test $(\mathrm{P}<0.05)]$.

\section{DISCUSSION AND CONCLUSION}

The apparent lack of efficacy of sulphur on 'CluthaGold' at harvest may have been caused by the long interval ( 35 days) and four infection periods between the last treatment and harvest, which included the susceptible preharvest stage. This compares with the 17 days and three infection periods intervening for 'Sundrop'. The greater delay in ripening shown by 'Sundrop' compared to 'CluthaGold' may also be related to the shorter interval between the last treatment and harvest for 'Sundrop'. No phytotoxicity was observed on the leaves, although some concave leaf cupping had been observed previously on sulphur-treated apricots (McLaren and Fraser 1993). The effect of sulphur rates was not consistent between cultivars and assessment times.

It could be claimed that sulphur reduced the level of brown rot on apricots because it delayed the development of the more susceptible ripe stage in the fruit by a few days. Indeed, with all the fruit being picked on the same day, those which were untreated may have been slightly more susceptible than the sulphur-treated. However, the other trials demonstrated that sulphur was effective at the flowering stage on apricots and nectarines, and on nectarines and peaches at harvest. Such effects were independent of the apricot ripening processes.

Sulphur reduced blossom blight in four of the six cultivars tested. No difference could be shown between blossom blight levels in the timed treatments compared with the untreated in 'San Castrese' and 'Flamecrest' but this reflects a generally low incidence of the disease in both these blocks at that stage. Sulphur gave significant disease control compared with the untreated on all cultivars at harvest with the exception of 'CluthaGold', and was particularly useful on the very susceptible 'Red Diamond' and 'Flamecrest'. This suggests that sulphur has potential to provide some control of brown rot under both organic and integrated fruit production systems. More 
trials are needed to determine the most effective rates, spray frequency and intervals close to harvest, while minimising the delay of ripening in apricots.

Interpretation of the effect of timing of the sulphur treatments is complicated by the exceptionally wet season which made it difficult to separate post and preinfection timings. Studies by Tate et al. 1995 indicate that preinfection spraying is more effective than postinfection or standard programmes. This one-year trial suggests that sulphur could be effective when applied after an infection period, but this is difficult to explain in view of the protectant-only activity of sulphur. Considerably more evidence is required to confirm post-infection activity.

\section{ACKNOWLEDGEMENTS}

This research was funded by the New Zealand Foundation for Research and Science Technology. We thank Greg Tate and Philip Elmer for discussions on this programme.

\section{REFERENCES}

Braithwaite, M., Elmer, P.A., Saville, D.J., Boyd-Wilson, K.S. and Whelan, H.G., 1995. Reduced sensitivity to DMI fungicides in Monilinia fructicola and efficacy of DMI fungicides for blossom blight control. Proc. 48th N.Z. Plant Prot. Conf:: 17-21.

Byrde, R.J.W. and Willetts, H.J., 1977. The brown rot fungi of fruit, their biology and control. Pergamon Press $171 \mathrm{pp}$.

Cross, J.V., 1996. Guidelines for integrated fruit production of stone fruits in Europe. IOBC Technical Guidelines III (peach, nectarine, apricot, plum and cherry) (in press).

Elmer, P.A.G. and Gaunt, R.E., 1994. The biological characteristics of dicarboximideresistant isolates of Monilinia fructicola from New Zealand stone-fruit orchards. Plant Path. 43: 130-137.

Hintze, J.L., 1989. SOLO statistical system. BMDP Statistical Software Inc., Los Angeles, CA.

McGuire, R.C., 1992. Reporting of objective color measurements HortScience 27: 1254-1255.

McLaren, G.F. and Fraser, J.A., 1993. Trials with sulphur for brown rot control on nectarines and apricots. HortResearch Internal Report IR 93-35.

McLaren, G.F. and Fraser, J.A., 1994. Effect of sulphur sprays on the quality of three apricot cultivars. HortResearch Internal Report IR 94-51.

Tate, K.G., Wood, P.M. and Manktelow, D.W., 1995. Development of an improved spray timing system for process peach in Hawke's Bay. Proc. 48th N.Z. Plant Prot. Conf::101-106. 